\title{
Small-State Nostalgia? The Currency Union, Germany, and Europe: A Reply to Jürgen Habermas
}

\author{
Wolfgang Streeck
}

With this chance afforded me by the editors to respond to Jürgen Habermas, I would like to persuade my readers and maybe even my critical reviewer to jettison once and for all the association (so staggeringly entrenched in Germany) that equates the Economic and Monetary Union (EMU) with "Europe" and even the "European idea." "To this end, I start with the by now trivial observation that the currency union, contrary to what was envisaged when it was established, has in actual practice been anything but a vehicle for an "ever closer union among the peoples of Europe." As point of fact, "United Europe" has never been so disunited in the last half-century as it is today. The accusations leveled at one another by states and governments are coming alongside renewed and often distressingly emotional hostility toward each other's citizens. At the state level, the accession process has collapsed, the U.K. is working to loosen if not end its membership, and Denmark and Sweden are now certain to keep out of the currency union. At the level of the lifeworlds of citizens, nationalistic clichés and national identifications have returned with a vengeance, boiling down again as before to dissociation and mutual disdain and threatening to put an end to the harmonization of European ways of life that we have enjoyed for so long.

It cannot be denied that this is vexing above all to Germans, who are realizing to their dismay that this same currency union, which was once touted as the keystone of their "Westernization" by governments of all stripes, is now threatening to isolate them from their neighbors. ${ }^{2}$ How much more astonishing must it seem that, in Germany, both government and opposition, in complete accord with industry and labor, continue to extol and fanatically strive to preserve the currency union as a sacrosanct national interest. Any thought of abolishing the Euro-by the Left or by the Right-is to be banished from the range of legitimate political discourse. This is accompanied by more or less explicit promises that the new German isolation will come to an end as soon as "we" will have rescued the otherswith "growth programs," Eurobonds, measures sponsored by "us" against youth unemployment, and so onfrom what is allegedly no more than a one-time, temporary "crisis" occasioned by a confluence of unlucky circumstances.
In fact, however, this will prove illusory, for as I explained in Gekaufte Zeit and elsewhere, the present conflicts are rooted in powerful differences in the structures and the ways of functioning of the national economies that technocratic hubris is trying to wedge together into a currency union. These differences are not just technical in nature; they trace back to long-standing national peculiarities in social structures, lines of class conflict, and collective ways of life which can only within narrow limits and for brief moments be politically manipulated. ${ }^{3}$ The European currency union, as I am certainly not the only one to claim, has superimposed on the neighboring yet different forms of national economic organization as they exist in Europe a unitary monetary order with which they cannot live equally well. ${ }^{4}$ That they could and would so, if not right away then in a few years, was and is the grand delusion of the EMU that is today breaking down, with unforeseeable damage to the peaceful and amicable common life of European peoples.

Here, now, we must inevitably contend with a couple of technical considerations, even if they essentially just repeat what I have already written in my book. Pace Merkel, Steinbrück and Habermas, the European currency union is not "Europe;" it is a multilateral agreement about a common currency and its administration. Insofar as it does "unify" Europe, it does so by depriving participating states of the possibility of pursuing their own monetary policy fitted to their specific needs. In particular, it hinders the revaluation and devaluation of their currencies against one another. In this respect, the internal organization of the currency union amounts to a return to the international gold standard that existed (at least on paper) between more or less industrialized countries up through the early 1930s.

Problems with an international gold standard or a currency union develop when the participating countries differ in their "competitiveness." In a common market, a less competitive country can find itself in danger of falling farther and farther behind the leading countries, since it is denied the possibility of improving its position through such emergency measures as devaluing its national currency. If such a country is to avoid progressive impoverishment, it must instead increase its economic performance through cost reduction—e.g., with respect 
to wages, pensions and public expenditures-while in the long run adapting its economic institutions and social structures to the demands of international competition. Here we speak of internal as the only remaining alternative to external devaluation, the latter being by definition not possible in a currency union. Governments that undertake "reform" in this sense, however, expose themselves to the risk of being perceived and repudiated by their own citizens as not acting in their defense but in the service of foreign interests. This was, as Karl Polanyi (1957 [1944]) pointed out, one of the chief reasons for the foundering of democratic states in the interwar period and the abandonment of the international gold standard in the 1930s. ${ }^{5}$

It is not that the problems of a common currency for differently competitive national economies were unknown when the European currency union was established. ${ }^{6}$ To the numerous and sometimes contradictory motives that flowed into the formal compromises over the EMU belonged the request by France and the Mediterranean countries that the German central bank, the Bundesbank, be replaced with a European central bank, whose monetary policy would better support the needs of their national economies. Up to then, European governments, if they did not want to get sidelined in the capital markets, had more or less to follow mechanically the hard currency policy of the Bundesbank, which carried high political risks for them domestically. So important was this demand especially to the French and the Italians that they were ready to sign off on contractual wording dictated by the German government-apparently in the expectation that later majority decisions would not necessarily abide by it. For Germany and the other export-oriented surplus countries, on the other hand, eliminating devaluation within the European Single Market was a matter of forever protecting their terms of trade against politically induced deterioration by their partner states devaluing their currencies. For this the German government was ready to see the Bundesbank and its hegemony in monetary policy communitarized, especially as it succeeded in making itself believe that the less competitive countries, under the pressure of the single currency, would "do their homework" and thereby guarantee the cohesion of the currency union on terms favorable to Germany.

More complex were the interests of the less exportoriented countries, where we find a colorful mix of hopes for permissive monetary and fiscal policies (apparently justified by the Schröder and Chirac governments' creative interpretations of the Maastricht Treaty), as well as for fiscal transfers for structural adjustment and social assistance from Brussels. An important role was played in this respect by modernization-oriented national elites. For them, the practice of external devaluation was a thorn in their side, since as a stopgap against declining competitiveness it spared their societies-not least of course their labor unions-from the "painful reforms" prescribed by neoliberal doctrine. In Italy, this current had been represented since the end of the war by the Bank of Italy and Milan's Bocconi University (Blyth 2013). Their ambition was and continues to be the thorough top-tobottom rationalization of Italy's political economy in the sense of a market-conforming "flexibilization," associated with a steady disciplining of policy and politics by the logic of the market and an ongoing realignment of social structure toward the functional imperatives of liberal market capitalism. Overall, their goal was and is thoroughly to eradicate all remaining pockets of resistance to the forward march into market rationality and market conformity, premodern or modern. This, too, sails today under the flag of "Europeanization," meaning not a slow horizontal combination and growing together of Europe's different countries but instead hegemonic unification through the authoritarian enforcement of a capitalist monoculture-a version of a capitalist society which one of its most prominent representatives, the former Bocconi economist, EU Commissioner, and Goldman Sachs functionary, Mario Monti-installed of all people by international High Finance as Italian Prime Minister but then ousted by the citizenry_identified with "the German model."”

The conflicts of interest connected to the currency union in the southern member states remained latent at first. A convergence of nominal interest rates that began in the early 2000s covered them over, as they allowed the national economies of the Mediterranean a more favorable entry to international financial markets than ever before. This was reinforced by relatively high national inflation rates. Meanwhile, Germany, with its low inflation, ${ }^{8}$ had to struggle with comparatively high real interest rates, which was connected in turn with low growth and high unemployment. For years, Germany was counted as Europe's "sick man." It was only the 2008 crisis that changed this. The debt-pyramid in the South collapsed after the sources of credit dried up and, contrary to what "the markets" had been secretly expecting under the currency union, the collectivization of debt was not forthcoming. ${ }^{10}$ At the same time, the German economy, with the help of the fixed low exchange rates effectuated by the EMU, ${ }^{11}$ flourished under the very same "over-industrialized" structure that had until recently been considered antiquated by "experts" of all types. In countries such as Italy and Greece, meanwhile, the neoliberal convergence program appeared to have come to a temporary standstill following a massive countermovement from their besieged societies, which among other things included election results viewed as inappropriate in Brussels and Berlin. 


\section{The Currency Union and the German Interest}

What explains the blind adherence of both government and opposition to the currency union in Germany? How are we to understand the extra-parliamentary debates among economists over its continuation, and how exactly does Jürgen Habermas of all people line up with the defenders of an institution whose contribution to the peaceful unification of European peoples has thus far consisted in undermining it? For the Christian Democratic Union (CDU) as well as the Social Democratic Party (SPD), as for the Federation of German Industries (BDI) and the Industrial Union of Metalworkers (IG Metall), the export opportunities and interests of German manufacturing are the clear priority. But these don't make very good public arguments; after all, not all citizens and taxpayers are employed at Mercedes or Bayer-indeed, a smaller and smaller portion of them are. Rather, it is the unknown costs of dismantling monetary union that must serve as the primary justification, either for "us" and "our" banks or, in more altruistic terms, for the savings of the middle and upper classes in the countries that would otherwise be looking at devaluation. A retreat, so the strategists of monetary integration tell us, would be more expensive than taking the bull by the horns and moving forward. Of course, here, too, the costs are unknown and will not be small either-an equation with two unknowns the result of which is nevertheless already clear for the Grand Coalition of the friends of the currency union.

What is interesting is the extra-parliamentary proxy war among mainstream economists close to the government-plus-opposition camp ${ }^{12}$ - parliamentary debates having gone out of fashion on Germany. Liberal economists should normally like an international gold standard, as it shields free trade from market-corrective political intervention and forces governments to respect the "laws of the market" as propounded by economic theory. In the case of the currency union, however, there were already early on doubts in Germany, prominently based at the Bundesbank, whether the democratic politics of other countries could be successfully disciplined into accepting without complaint the social consequences of a common market with a hard currency. These doubts were initially allayed through precautions like the "No Bailout" provision. But in the crisis this proved to be a self-delusion. Still, the majority of German economists, anxious to preserve their good relations with the ruling powers, are eager to avoid giving up on currency union. They insist, however, on a further tightening of international controls over the fiscal policies of deficit countries, far beyond that which has already been added to the original agreements by the so-called "Sixpack."13 Their opponents, many within the party calling itself "Alternative für Deutschland"
(AfD), distinguish themselves from the majority only in that they believe such a solution, unfortunately in their view, to be politically unenforceable, making them fear that the surplus countries will end up continuously having to make transfer payments to the Mediterranean states at a level that will undercut their own prosperity. ${ }^{14}$ When neoliberalism costs your own money, it no longer serves its purpose.

Here I allow myself a moment for a clarification, as some of my critics believed that my Keynesian suggestion (which I offered with little hope of seeing realized) to introduce a minimal level of exchange rate flexibility into the currency union on the model of the Bretton Woods system is identical with the AfD program. I find the AfD's skepticism to be realistic on whether the deep national and international, structural and institutional reforms that the neoliberal (still-)supporters of the currency union consider indispensable for its functioning would be enforceable. However, unlike the AfD, I do not regret this but rather welcome and even hope for it, since I desire nothing but failure for the neoliberal convergence program for a market-united and marketconforming Europe. At the same time, I believe the current transfer payments of various types from North to South which are unavoidably coming are of such dimension that they will overtax the "solidarity" of the northern countries - if not of their elites, then at least of their voters who will have to foot the bill. ${ }^{15}$

For me, the most likely prospect for politics and society in a currency union without currency flexibility is a long-term international conflict over, on the one hand, how much sovereignty to be wrung from the southern countries and, on the other hand, how much financial compensation to be provided by the northern countries. As to the former it will be too much for the South and too little for the North, and concerning the latter it will be the reverse. ${ }^{16}$ So, at the expense of European peace, on both sides their own contribution to the currency union will appear too high while that of their counterpart will seem too low. The really existing currency union will become chronically unstable as a neoliberal economic order through democratic politics in the South, and as an international welfare state through democratic politics in the North. The consequence can only be a further de-Europeanization of European politics, together with an imperialistic division of EU member countries into ruling and ruled, along the divides between different social structures and economic cultures.

\section{Habermas, Germany, and European Democracy}

To sum up thus far: The currency union is a program for forcing together the economies and ways of life of the 
European peoples, pitting them against one another and dividing them politically into first- and second-class nations. It is the culmination of the European variant of the neoliberal immunization of expanding capitalist markets against egalitarian-interventionist democratic politics, as has become the dominant trend worldwide since the postwar order of democratic capitalism has come to an end. The institutional "reforms" currently being pushed through under the pretext of "crisis management" threaten - at both the national and European levels-to impose in something like a coup d'état a Hayekian economic constitution while skillfully cutting off any route of escape.

How can it be that someone like Jürgen Habermas would advise us to hold on to such a monstrosity, if even its most devout economic partisans keep saying that it only stands a chance of survival at the price of "reforms" that will make it more monstrous still? I am guessing that Habermas is banking that a development like the one I am predicting would be so painful in the long run for national states and their citizens that they would have no choice other than stop it by transferring national democratic competences "upward" while democratizing European institutions-and that this option is realizable in the here and now (for example, in the four years following the 2013 German federal elections). Now facts are typically trivial — even hideouscompared to visions, so that one may feel a bit mean for even mentioning them. And perhaps it is true that one operates on different levels, such that the visionary is in fact entitled to ignore facts that contradict to his vision: on the long road of political mobilization by charismatic imagery, portraying the desirable as possible can sometimes in fact, via the political mobilization caused by its charisma, make the desirable more possible. Even if it doesn't work that way, visionary rhetoric always retains the tactical advantage of being able to make warnings of the resistance of the real world appear similarly rhetorical — to wit, as rhetoric fainthearted or even malicious, aimed at obstructing the desirable and eliminating it from the possible. If the warning comes with an appeal not to give up a bird in the hand for two in the bush, then what offers itself as a strategy is the diagnosis of a "nostalgia" obstructing the other party's clear vision-as is the case here. ${ }^{17}$

I prefer a different tack, first making the strongest case possible for the position I take to be wrong and criticizing it from there. The most systematic argument for preserving the currency union for the sake of European democratization is conveyed by the neofunctionalist theory of integration that hails from the 1960s and still resides in the back of many people's minds. To give a simplified formulation, it supposes that, mediated by objective functional relationships, the Europeanization of one sector or policy sphere must over time lead to the Europeanization of other, adjacent sectors and policy spheres. ${ }^{18}$ Whether and in what sense this might be the case, and since when perhaps no longer, has often been debated. A recent example in which a neofunctionalist promise proved illusory was the socalled "completion of the internal market" that Jacques Delors made his signature project during his two terms as Commission president. Skeptics on the side of unions and social democrats, of which there were quite a few, got to hear from Delors that a market cannot in the long run function without a "social dimension" as it requires legitimation and because unlike a social welfare state one cannot "love" a market. According to Delors, this was why one can proceed with the integration of Europe by instituting free markets as their social embedding would inevitably be following before long. However, it soon enough became apparent that, unlike most people, a market can function quite well without being loved. Indeed, after the complete failure of all attempts to install at the European level a common social policy to flank and modify the internal market, the term "social dimension" is today avoided in Brussels like a pest.

A well-known problem in academic discussions of the neofunctionalist approach is that beyond a certain level of penetration of integration processes into national systems objective constraints may no longer be sufficient to carry Europeanization. Instead what happens is "politicization"- that is, political countermovements that make further steps toward integration dependent on favorable conditions of consensus and power. Even a currency union optimally protected from retrenchment may then be unable to advance toward a political union "on its own." To be sure, Habermas may be aware of the necessity of agency for any realistic theory of neofunctionalist integration. His solution seems to be to try to inscribe and talk into German politics a national interest in European democratization, assuming that Germany, if it but had the will, could somehow bring about European democracy out of its specific enlightened self-interest. The "narrative" 19 evoked here is the classic West German tale-in the style of Helmut Schmidt to Helmut Kohl—of a Germany that is too small to be feared and too large to be loved, and which must therefore, for its own sake, dissolve itself into a greater Europe. The pursuit of interests thus coincides with the renunciation of interests, so as to cancel itself out. In other words, Germany needs or at least cannot retreat from the currency union, without however being able to govern it. But of course governed it has to be if not by Germany, then by itself. What matters for Germany is that "Europe," with Angela Merkel, does not "fail," even at the expense of other German interests, lest the anti-German cantankerousness not end and the old drama return. Wouldn't this be the only possible 
program for a very grand coalition of the realistic and the willing?

Wayward and disorderly as the world is, that which to the partisan observer seems practically or even logically necessary all too often simply refuses to happen. Can the project of a supranational European democracy really ride the coattails of the currency union, strategically insisting on its irreversibility, in the hope that the German government will someday find itself compelled to hand the reins to a democratic constitution of Europe? This would require a readiness and willingness to let a European Parliament, whose permanent majority would come from countries dependent on equalization payments, determine the price to be paid by German voters for the currency union's survival-and thus deprive itself of the possibility both of negotiating that price and hiding it from the electorate. But who would ask of an electorate to agree to financial transfers higher than already agreed upon, after having already been asked to accept neoliberal "structural reforms" together with a constitutionally enshrined consolidation of public finances? A government that was serious about shifting from German to European democracy would have to reach its goal within four years at most, supplanting German with (real) European elections if it wants to stop or make inconsequential what Habermas wanted already for the September 2013 elections: namely, a dramatic vote increase for parties like Alternative for Germany. ${ }^{20}$

In my view, what Habermas and others have in mind as they hope for a democratic turn in Europe as a solution to the crisis of Europe would amount to nothing short of a new re-founding of Europe, a second foundation more or less $a b$ ovo, a leap out of the history of the past three decades, that would turn the supranational institutions that have grown up in Europe upside down by revolutionary decisions made within their confines-as if what is and what has come about had no meaning for what is to grow out of it in the future. Habermas downplays this difficulty; in his view, it looks like as though the problem was simply to "extend" (ausbauen) the currency union with its central bank, the latter sometimes acting together with the Commission and the International Monetary Fund as the so-called "Troika," with their diverse instruments of economic and financial control by adding to it a balanced dualism between Council and Parliament and converting the Commission into a supranational executive- the same currency union, that is, which at present serves no other purpose than to eliminate precisely those political capacities to correct market outcomes that Habermas hopes to restore through supranational democratization.

How can what would amount to nothing less than a revolution be achieved through reform, within a framework of institutional continuity? Who would sit at the convention that would have to break with the present and embark on a new and better future, if not the interminable Giscards, van Rompuys, Barrosos, Junkers e tutti quanti-the representatives, that is, of the same political class that drove already the last "constitutional" convention into the wall once visionaries like Josef Fischer had conveniently lost interest in it? Is it mere faintness of the heart if one remembers that, as it stands, any reorganization or refounding of the European Union would have to be ratified by every member country, including the U.K., France, Denmark, and the Netherlands (at least two of whom are preparing extensive catalogues of previously-Europeanized responsibilities they now want returned to the nationstate)? Is it just a lack of imagination if one insists that, considering the fundamental heterogeneity of European societies and their economies, any conceivably negotiable European democracy, if it ever came to pass, could only be a consensus democracy, a consociational democracy, ${ }^{21}$ with a huge catalogue of minority rights and protective clauses-above all in its financial constitution-that would be intelligible only to experts in constitutional law? Might one ask if there is even one government in Europe today that has the will or the mandate to renounce its and its fellow governments' status as "Masters of the Treaties" and allow a constitution that would be more than another "constitutional treaty?"22

In point of fact, this is only the smaller problem. However "democratic" a supranational-European democracy might be, it would be worthless if the relations between its institutions and the market, especially finance and labor markets, between politics and the economy, between democracy and capitalism remained as they have become in recent decades. If a "European people" electorate were permitted to choose between (let's say) a Schulz and a Barroso, however directly or indirectly, without there also having been a fundamental change in the institutional architecture of Monetary Union-i.e., in the pentagon of the European Council, Parliament, Commission, Central Bank, and Court of Justice — nothing would be gained. What would then be called "European democracy," with parliament, government, public sphere and whatever, would be nothing but a further layer of postdemocratic paralysis imposed from above on national post-democracies. The governing would be done by Mario Draghi and his finance technocrats, together with their lifelong friends from the private money-making industry liberally supplied by them with public funds - a camarilla that could in fact and in law prohibit any meddling into their affairs by popular-democratic politics. Their "reform program" - substituting the archaic clientelism of Sicily or Greece with the postmodern clientelism of the new financial capitalism-would continue unabated. It is 
nothing short of surprising how even the good-willed among German currency union supporters are offering to the Southern and Eastern countries as "modernizing" progress toward greater social justice the very neoliberal economic order that they oppose in their own countries, in silent collusion with Draghi \& Co. as they impose that order on Europe even though wherever it has been implemented it has led to a decoupling of mass incomes from productivity growth and a continuous increase in social inequality.

Post-democratically sterilized elections are not worth the paper their ballots are printed on. In my book, I describe a new looming Hayekian compromise between democracy and capitalism in which the latter is immunized against the former. Neoliberal capitalism and electoral democracy can live together peacefully provided democracy is deprived of its capacity for egalitarian political intervention in the "free play of market forces." One reason why it seemed in recent decades politically advisable to drain politics of its content in this Hayekian sense was so-called "globalization:" the embedding of states in markets superseding the embedding of markets in states. ${ }^{23}$ The cantus firmus emanating from among current discussions about the incompatibility of globalization and democracy ${ }^{24}$ (meaning of course the non-sterilized kind of democracy) draws its plausibility from the multiple external effects faced by communities whose markets do not stop at their political borders. Habermas and others who diagnose me with a hankering for "small-statism" ("Kleinstaaterei")—for a retreat back into "the 1960s and 1970s corral of the nation-state" and behind a political-economic "Maginot line"-apparently believe that a European superstate could be large enough to resist the pressure of "the market" and restore egalitarian democracy. What supports the optimistic expectations regarding what we may call "large-statism" in return ("Großstaaterei"), is beyond me. The U.S., Japan, China and the recently celebrated BRICS countries, to say nothing of Bangladesh and Myanmar, are certainly more than capable of producing neoliberalizing external effects aplenty for a Europe with the Euro and popularly elected presidents of Council and Commission just as well as for a Europe without them. And if one wants to see how even a large state can appeal to market constraints to dispossess democratically and economically the ordinary-people majority of its population, one need look no further than the United States.

\section{Once Again and Still: Democracy and Capitalism}

Unlike Habermas, I do not believe we can speak meaningfully about the future of democracy, in Europe or elsewhere, without at the same time speaking about the future of capitalism. Put otherwise, we cannot do democratic theory without political economy. As the sensible social democrat that I have long been, I concede with shocked astonishment that the really important questions today are those being most likely to be discussed in the vicinity of movements like ATTAC ${ }^{25}$ : questions about how globalization might be retailored or even-horribile dictum-scaled back to become compatible with egalitarian democracy, instead of questions about how democracy must itself be globalized in the sense of de-democratized to accommodate the "objective constraints" ("Sachzwänge") of global "markets." Compared to the problems of humanity discernible behind questions of this kind, and to the political tasks that might follow from them, the renunciation of "small-statism" 26 and the reeducation of the citizens of European nation-states into European citizens appear to be child's play-questions and tasks that can and must boil down to nothing less than the taming of global financial markets by providently cutting off transnational routes of contagion, and more generally by domesticating an economy that has to produce higher and higher mountains of debt to generate lower and lower economic growth with a more and more unequal distribution of incomes.

Not least as a result of the discussion about my book, I am coming to suspect that European integration, as it developed since the era of Jacques Delors, has become a modernization project that has ceased to be modern, and whose last chance to become democratic has long been missed. Should we really want to sustain, under high costs, a centralized fiat money system that cuts European nation-states off from the European political economy while exposing their societies to a one-size-fits-all pressure for conformity-given that nation-states still remain the most politically potent institutions in Europe? Should we, in doing so, rely on a market-correcting European-democratic politics somehow show up like a deus ex machina at the last minute-which may already have arrived-and somehow change things for the better? I cannot by any stretch of my imagination see from where-in theory or in historical experienceI am supposed to draw the optimism this requires.

What I am seeing instead is how surprisingly well the remaining national institutions of Europe stood their ground against the Blitzkrieg unleashed after 2008 by the techno- and monetocrats on the European peoples. ${ }^{27}$ Democratic elections deposed Monti and Papademos, the collection officers dispatched to their own countries by the financial markets and the allied European empire; the German Constitutional Court has made sure that at least a select few members of the German Parliament were allowed to examine the bailout agreements before they had to nod them through; the emergence of a party like Syriza has pushed down, a least a little bit, 
the price that the people of Greece had to pay for the extravagances of their governments and their sponsors in Brussels and New York; the Occupy movement for a time reminded banks and governments that most people speak a different language than the technospeak of the financial system; again, the German Constitutional Court, while being mercilessly mobbed by the experts in European law (Europarecht) fearful of their domain, managed for at least one or two days of proceedings to lift the veil of the press releases behind which the ECB makes and hides its "autonomous" decisions; and so on and so on. The rights to vote and to strike and to express one's views in public demonstrations remain firmly anchored at the national level; when and if they will ever be established at the European level is entirely unclearand let us recall that the ECJ has already started to define the right to strike as secondary to the "four freedoms" of the common market (Höpner and Schäfer 2010). What I said in my book on the value of these and other national institutions was no more than this: if we did not have them-even though the way they are they may not be able to offer the ultimate answers to the current crisis of capitalism - the project of a democratic political economy in Europe would not be as troubled as it is today but it would long have ceased to exist.

Time must be gained if it cannot be bought - that was the essence of the final pages of the book to which Habermas and others have reacted. And only for this purpose did I suggest that we not surrender the sole positions from which we might still slow down if not halt the march of the neoliberal-supranational Leviathan. My concern in the book is to preserve the possibility of converting the remains of postwar social democracy into barricades against technocratic encroachment, in the best case to accumulate a set of hard "restrictive conditions" 28 for the politics of neoliberal social reorganization - conditions that this time would be not market constraints but, as it were, lifeworld constraints. Do I have to say again that this can only be a subversive temporary expedient, a means for achieving a stay of execution, and that the nation-state as a form of political organization will obviously not be able to support the post-capitalist political economy we need and must somehow build?

Who knows what such a political economy will look like? What I believe to know for sure is that the project of Draghi, Barroso, Schäuble and others is not a suitable vehicle for realizing it: the only direction in which it can move is the opposite direction. What, then, is the problem with manifestations of civil disobedience resisting a technocratic policy that is about to divest itself of its obedience to the citizenry? Let us wish that the Greeks, Italians, Spaniards and others might succeed where the Germans are hindered by their peculiar national amalgam of export interests and Euro-idealism-namely, to gain time for a democratization of the European political economy that would be worth its name.

\section{NOTES}

1. This equation seems to lay in an interesting continuity with the "Deutschmark patriotism" of the German postwar period: the political community as monetary community, with the symbol of its unit of currency as totem and monetary patriotism as a precursor or substitute for constitutional or way-of-life patriotism.

2. Old clichés come back into the light of day that we long thought to have forgotten. On the Left we hear from the co-chair of the French Parti de Gauche, "Of those who have a love of life, no one wants to be German... We are happy to have children... (the Germans) "are poorer than average, live not as long as others, have no kids, while foreigners go on the run since they don't want to live with them any longer" (Spiegel online, June 10, 2013).

3. I am not alone in this conviction; see, for example, the important essay by Peter Hall, "The Economics and Politics of the Euro Crisis" in German Politics 21:4 (2012): 355-371. Hall distinguishes between national economies with exportled growth and those with demand-led growth. Lucio Baccaro says something similar in a recent, as yet unpublished paper on profit-led and demand-led capitalism, and he points out that the German economy has long found itself alone in the EMU on its path toward profit-driven growth.

4. The most important insights on this stem from Fritz Scharpf. For an overview, see Fritz W. Scharpf, "Solidarität statt Nibelungentreue" in Berliner Republik 12:3 (2010). Scharpf, "Mit dem Euro geht die Rechnung nicht auf" in Max Planck Forschung 11:3 (2011), 12-17. Scharpf, "Rettet Europa vor dem Euro" in Berliner Republik 14:2 (2012), 52-61. And also Martin S. Feldstein, "The Euro and European Economic Conditions," (Working Paper no.17617, Cambridge, Mass: National Bureau of Economic Research, 2011). Oskar Lafontaine, Heiner Flassbeck, and Sara Wagenknecht have recently joined up with this argument, though on slightly modified grounds. Whoever does not want to side with them might do well to recall the great sociologist and cosmopolitan homo politicus Ralf Dahrendorf, whose December 11, 1995(!) interview in Der Spiegel reads as if it were from today:

"DAHRENDORF: The currency union is a grave error, a quixotic, reckless, and misguided goal, that will not unite but break up Europe.

SPIEGEL: But the essential idea is precisely convergence.

DAHRENDORF: It won't work, for their economic cultures are too different..."

Is Dahrendorf, of all people, a nostalgic for the (German) nation-state? For this, see Jürgen Habermas, "Demokratie oder Kapitalismus? Vom Elend der nationalstaatlichen Fragmentierung einer kapitalistisch integrierten Weltgesellschaft" in Blätter für deutsche und internationale Politik 58:5 (2013), 161-5.

5. See also Mark Blyth, Austerity: The History of a Dangerous Idea (Oxford: Oxford University Press, 2013), 184. "You can't run a gold standard in a democracy," referring to Eichengreen (1992).

6. In 1944, the still-living memory of the disaster of the interwar period led the Bretton Woods conference to provide the new world economic order with limited flexibility in exchange rates, in order to take account of the different political conditions and needs of participating countries. Countries with 
strong unions, communist parties, or pent-up demands for social policy could gain breathing room through occasional devaluations and were not forced into market conformity through anti-union and anti-socialist "structural reforms."

7. Monti on January 10, 2012 in an interview with Welt Online, which was the first nail in his electoral coffin: "You know, I have always worked for an Italy that would be as similar to Germany as possible. I always wanted a competitive Europe as committed as possible to the idea of a social market economy originated by Ludwig Erhard. You see, I feel very German..." Compare once again Dahrendorf in the Spiegel interview cited above from December 1995: "The currency union project instills into countries German behavior, but not all countries want to act like Germany. For Italy, occasional devaluations are much more useful than fixed exchange rates, and for France higher state expenditures make much more sense that rigid adherence to a stability doctrine that is used mainly by Germany."

8. The question is sometimes posed by the German Left whether a German wage-policy coordinated with the Mediterranean countries could raise local inflation rates and so reduce German real interest rates (Lafontaine explains his rejection of the Euro in terms of the failure of a coordinated wage policy to materialize, which he believes is essential to a wellfunctioning currency union). This overlooks the differences in economic structure. A strong national economy oriented to industrial production must not face international price competition, but is in a globalized economy continuously exposed to the risk of relocation of production abroad, that is, it is exposed also to wage and employment competition. This explains the notorious wage restraint of German industrial labor unions since the 1990s (for many others see Britta Rehder, Betriebliche Bündnisse für Arbeit in Deutschland: Mitbestimmung und Flächentarif im Wandel Schriftenreihe des MPIfG no. 48 (Köln: Max-Planck- Institut für Gesellschaftsforschung, 2003). So in May 2013, the once so redistribution-conscious Industrial Union of Metalworkers (IGM) agreed, despite outstanding economic conditions, to a wage increase of no more than $3.4 \%$ for 10 months and $2.2 \%$ for the following 8 months.

9. That we today get to hear from the export industry and its representatives in politics and the public sphere that "Germany" is the greatest beneficiary of the currency union and therefore should not make too much fuss over having to "rescue" of financial oligarchs is a further example of the astonishing presentism of the political public.

10. At least initially - today it is provisionally and surreptitiously carried out by the ECB under the guise of monetary policy.

11. And, of course, not on account of the so-called "Schröder Reforms," which almost exclusively concerned the bottom rung of the labor market and played no role for the export industry.

12. I am ignoring the few remaining Keynesians here, who are more or less all linked to the trade unions and have therefore nothing to say, having been surprisingly persuaded by their sponsors into becoming supporters of fixed exchange rates.

13. Representative here is Dennis Snower, President the Kiel Institut für Weltwirtschaft in a debate with Bernd Lucke, AfD founder, Frankfurter Allgemeine Sonntagszeitung, May 19, 2013: "If a state violates the rules, it is-automaticallypenalized. Value-added taxes are automatically raised, state expenditures are automatically cut with a lawnmower... [So] the state must be forced by an independent institution, like in monetary policy, to arrive at a constant debt ratio... Decisions on the debt path cannot be left ... to short-sighted politicians... The rules will be implemented by an independent institution, where boring people like me make the decisions."
14. In this sense, the chair of the Scientific Advisory Board of the German Finance Ministry, who grants the Euro no more than five more years of life (Die Welt from April 21, 2013, FAZ from April 24, 2013, Focus Money from April 30, 2013), as well as the former chief economist at Deutsche Bank (Manager Magazine Online from April 19, 2013, accessed May 1, 2013).

15. Let there be no misunderstanding: I am fully behind the idea that the well-to-do should share with the less fortunate. In an increasingly degressive tax system and in light of the possibilities for affluent organizations and individuals to choose between differently discerning tax worlds, it is however to be expected that those who are expected to produce innerEuropean solidarity would also be those who would have to pay for the consolidation of their national budgets by having their pensions, public assistance, and public investment in education cut. Moreover, the governments of the North will make their financial support for those of the South dependent on the latter at least occasionally taking their peoples on a neoliberal ride, as prescribed by the "Memoranda of Understanding" formulated by the ECB and others. While the AfD worries essentially about "our" money, for me what is at stake is sparing the Mediterranean countries decades more of experiences like those of the Greeks or Spanish under German supervision, as well as sparing the Germans the resulting severe discontent.

16. The German export industry could presumably still live with it. The continuation of the currency union would mean that the price of entry into the markets of other states would be paid instead by German taxpayers, like a devaluation in the form of lower sales.

17. Nostalgia is a mental disease. According to Wikipedia, the word was fashioned as a medical term by the Swiss psychiatrist Johannes Hofer (1662-1752) from the Greek words vó $\sigma \tau \varsigma$ (returning, homecoming) and $\alpha \dot{\alpha} \gamma \mathrm{\gamma} \varsigma$ (pain). We generally try to avoid making ad hominem arguments in public debates, especially of a psychiatric sort, but every so often one can sadly slip through. It is surprising though how many other responses to my book have casually disseminated Habermas's catchword as if it amounted to a knock-down argument, apparently unaware of the principle, Quod licet Iovi, non licet bovi.

18. The terminus technicus is "spillover" and its locus classicus is Ernst B. Haas, The Uniting of Europe (Stanford: Stanford University Press, 1958).

19. I don't want to comment on the surprising spread of this social-constructivist term into the jargon of our "Europapolitiker"-from Merkel to Trittin (The Greens) and Steinbrück (SPD), who can hardly be accused of preference for the soft. For me, therein lies a remarkable public admission that a new PR strategy aimed at the heart is all that they are willing and able to offer their nationally disempowered electorates. Rainer Hank recently showed in Merkur how very watchful we have to be for the implications of such a story, under the title "We Europeans: After the Lost Innocence." Hank's article directed me to the remarkable interview given by Hans Joas in the Frankfurter Allgemeine Zeitung in October 2012, in which he warns of a "sacralization of Europe" (http://www.faz.net/aktuell/wirtschaft/ soziologe-hans-joas-mich-schaudert-das-tremolo-in-deneuropa-reden-11916327.html; accessed on August 8, 2013).

20. Expecting from this push for the German Left at last to unveil vis-à-vis the voters and carry out the Europolitical democratic program that he expects the Left to harbor. Experience should suggest an entirely different effect, namely the reverse.

21. And this means: not a majoritarian democracy politically organized along class lines, as in some European nation-states. See Arend Lijphart, Patterns of Democracy: 
Government Forms and Performance in Thirty-Six Countries (New Haven and London: Yale University Press, 1999).

22. How about Ireland, which loves the European Union precisely because it became fully sovereign only through its membership - and which, even after its European "rescue," doesn't dream to bring its tax system and corporate law (to say nothing of its data protection law) into line with "Europe" or even Germany? And countries like the Baltic states, which certainly did not join the EU to have their national independence, for which they fought and suffered for decades, ceded to another central government-this time in Brussels instead of Moscow? And so on.

23. Speaking of my nation-state nostalgia, already about a decade and a half ago I have described, in the introduction to an edited volume, the hollowing-out of democratic-national politics by globalization, which was then already in progress but had so far been largely ignored or played down (Streeck 1998).

24. See, e.g., Daniel A. Bell, Beyond Liberal Democracy: Political Thinking for an East Asian Context (Princeton: Princeton University Press, 2006).

25. "Action for a Tobin Tax to Assist Citizens" - an international social movement that is seeking alternatives tio "globalization".

26. The polemic against "small-state nostalgia" alleges that small states with their own currencies do not "function" as well as large ones, or as small ones without a currency of their own. Doubts about this are well-founded. Compare Denmark or Sweden, which have for decades been left in peace by international speculation, with Greece or Portugal. Another undercurrent that is, interestingly, found more and more among German progressives, is the suggestion that "Europe" can only "assert itself in the world" if it is large enough and strong enough to stand up to the U.S. or China-in the parlance of Max Weber (see, e.g., Max Weber, Gesammelte Politische Schriften (Tübingen: J.C.B. Mohr (Paul Siebeck, 1988 [1921]), 142-5), that Europe, like Germany in the early twentieth century, has for "cultural" reasons not just the option but the obligation to become a "power state" ("Machtstaat"). Such representations seem to me as unrealistic as they are dangerous. Should "Europe" really compete militarily with the U.S., whose "defense" budget is larger than that of all other states combined, so that "we" can, like them, shoot "our" way to oil and credit? That would be a non-starter, if only because neither France nor the U.K. are going to surrender their nuclear arsenal to a Europe in which Germany is playing a leading role. Instead of seeking refuge from small-statism in large-statism, one should at the very least make an attempt to use the typical fragmentation of Europe as an invitation to a non-centralizing response to "globalization." Or is it already a given that the U.S. or China represent the political organization of the future?

27. Habermas sees this quite well; see the example he mentions in Portugal. This makes his criticism of my alleged nation-state nostalgia all the more astonishing.

28. This expression originally comes from Otto Kirchheimer. See, e.g., Joachim Bergmann et al., "Herrschaft, Klassenverhältnisse und Schichtung. Referat auf dem Soziologentag 1968" in Verhandlungen des Deutschen Soziologentags (Stuttgart Enke, 1969), 67-87.

Wolfgang Streeck is Professor of Sociology and Director at the Max Planck Institute for the Study of Societies in Cologne, Germany. In 2013-14, he was Theodor Heuss Professor at the New School for Social Research, Department of Political Science. 